\title{
Burn the Witch! A Comparison between the Portrayal of Sorceress Babylon in Isaiah 47 and the Figure of the Witch in Maqlûu
}

\author{
Alinda Damsma | ORCID: 0000-0002-7610-0687 \\ Department of Hebrew \& Jewish Studies, University College London, \\ London, United Kingdom \\ a.damsma@ucl.ac.uk
}

Published online: o6 October 2021

\begin{abstract}
In chapter 47 of the Book of Isaiah the fall of Babylon is described in metaphorical language: the arrogant queen Babylon is condemned for having practiced witchcraft since her youth. The evil which she inflicted on her victims will befall herself, and her downfall will be swift and without warning. Her dire fate follows that of her fellow sorcerers, who have perished in fire and flames. This article compares the portrayal of Babylon and her demise in Isa 47 with the Mesopotamian anti-witchcraft series Maqlû and discusses the shared terminology and the striking similarity of themes, such as the indictment of the witch, the gender-stereotype, the reversal of fate, and the condemnation to death by burning. The thematic, and sometimes lexical, overlap may indicate that Deutero-Isaiah incorporated Mesopotamian ideas about (counter-)witchcraft in his own composition, being exposed to local magico-religious thought whilst maintaining a critical stance towards it.
\end{abstract}

\section{Keywords}

Book of Isaiah - Deutero-Isaiah - Babylon - witchcraft - Mesopotamian literature - Maqlû 
In loving memory of my father, the Rev. Andries Jacob Damsma, and our time in "Babylon"

In the middle of Deutero-Isaiah's composition we find a foreign-nation oracle which is directed against Babylon: Isa 47 announces the city's imminent downfall and humiliation, which will pave the way for the salvation and exaltation of Zion. ${ }^{1}$ Babylon's demise is depicted in metaphorical language. The city is personified as a woman, an arrogant, majestically enthroned queen, who revels in earthly pleasures and oppresses the weak. ${ }^{2}$ She is accused of having practiced sorcery from her youth; with the help of magical knowledge and aided by her fellow sorcerers she wreaked havoc and deemed herself untouchable, thanks to her craft. However, all the evil which queen Babylon inflicted on her victims will befall herself, and this reversal of fortune will end in her swift and sudden destruction, just like the fate of her companions, who have perished in fire and flames. Deutero-Isaiah's portrayal of Babylon as a witch contains intriguing, thematic (and sometimes lexical) allusions to Mesopotamian anti-witchcraft materials, most notably to the Maqlû series of incantations, which is not only the longest but also the most important text directed against witchcraft from Mesopotamia. $^{3}$

1 On the identification of Isa $40-55$ as an authorial or at least redactional unity from the Middle Ages onward, see Blenkinsopp, Isaiah 40-55, 69-81; cf. Goldingay and Payne, Isaiah 40-55, 1:4-8. However, there has been a tendency in the last few decades to reassert the unity of the book of Isaiah; for a critical discussion of this trend and further literature, see Rendtorff, "Book of Isaiah."

2 On the personification of cities as royal female figures in the Hebrew Bible and the supposed mythological origin of this imagery, see Fitzgerald, "Mythological Background." On the frequent usage of the terms בַּת a a a a titles for capital cities, see Fitzgerald, "BTWLT and $B T . "$

3 For a general discussion on Mesopotamian beliefs in magic and divination, see Farber, "Witchcraft, Magic, and Divination"; Schwemer, "Mesopotamia"; and Thomsen, "Witchcraft and Magic." On the vast Mesopotamian anti-witchcraft corpus, see Abusch, "Witchcraft Literature"; Abusch and Schwemer, Corpus. For an introduction to the Maqlû series in particular, see Abusch, Witchcraft Series Maqlû, 1-40. It is beyond the scope of the present study to discuss the treatment of witchcraft in the Babylonian and Assyrian law collections, or the rare attestations of actual witchcraft accusations. For a discussion on these topics, see Rollin, "Women and Witchcraft," 42-43; Schwemer, "Mesopotamia," 41-42, 55-57; cf. Hamori, Women's Divination, 211 n. 16. 
Maqlû means "burning" in Akkadian, which is a reference to the burning of a clay figurine, representing the witch, in a brazier during a lengthy nighttime ceremony aimed at the indictment and symbolic destruction of the witch and her witchcraft. The ceremony's main participants were the ăšipu, the socalled "exorcist," 4 and the witch's victim, who was usually male and a member of the upper class. The Maqlû rituals counter-acted the destructive magic that the witch had inflicted upon the victim; they would release the victim from the witch's control and prevent any future attacks of witchcraft. The Maqlû composition, which in its current form is probably a creation of the early first millennium вСЕ, ${ }^{5}$ comprises of eight tablets of incantations and a ritual tablet, the latter serving as a manual for the entire ceremony. All the extant Maqlu witnesses date from the first millennium BCE and are of northern and southern Mesopotamian provenance.

According to the traditional critical assumption, Deutero-Isaiah was composed in the last decade of the Neo-Babylonian empire (ca. 550-539 BCE). The author lived in one of the Judean communities in Babylonia, thus witnessing the empire's intense political upheaval in the 540 and drawing hope from it. ${ }^{6}$ Given the probable date and location of Deutero-Isaiah's composition, the author may have been familiar with the Mesopotamian anti-witchcraft materials, or at least with some of the ideas that are found in them. Towards the end of this study, I will discuss how the composer may have been acquainted with Maqlû, or with Mesopotamian witchcraft beliefs in general, but first I shall explore the thematic and lexical parallels between Isa 47 and Maqlu in greater detail. ${ }^{7}$

4 As a member of the temple clergy, the âsipu was an expert in defensive, protective rituals to ward off illness and other misfortune caused by supernatural forces and fellow human beings; as such he was the primary opponent of the witch. For a discussion of the āšipu and his craft, see Ritter, "Magical-expert"; Scurlock, "Physician, Exorcist." It is important to realize that magic per se was not frowned upon in Babylonia, and it was by no means synonymous with witchcraft or black magic. The äšipu and the witch used the same incantations and ritual techniques, yet the witch practiced magic with evil intentions and in secret, which rendered her craft illegitimate; cf. Farber, "Witchcraft, Magic, and Divination," 1898; Rollin, "Women and Witchcraft," 35 .

5 Abusch, Witchcraft Series Maqlû, 5 . However, according to Abusch's reconstruction of Maqlû̀'s textual history, a shorter proto-form of Maqlû may have already existed in Assur by the end of the Middle Assyrian period.

6 For an extensive, recent overview of the scholarly discussion on Deutero-Isaiah's date and provenance, see Silverman, Persian Royal-Judaean Elite Engagements, $61-87$ and the literature cited therein.

7 The textual basis for the biblical verses is the $B H S$, and the English translation is my own. As for Maqlûu, I have used the composite transcription, largely based on the Nineveh Assyrian textual tradition, and the English translation as published in Abusch's text-critical edition The Magical Ceremony Maqlû. Abusch's choice for a composite text lies in the fact that the 
In Isa 47:6a God addresses Babylon as follows:

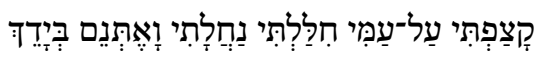

I was angry with my people,

I profaned my heritage;

I delivered them into your hand.

Although God commissioned queen Babylon to punish his people, it becomes clear in v. $6 \mathrm{~b}$ that she acted over-zealously as a divinely appointed punitive agent:

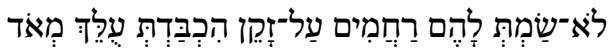

\begin{abstract}
You showed them no mercy;
on the elderly you made your yoke

exceedingly heavy.
\end{abstract}

The harsh treatment of the aged shows the extent of Babylon's abuse of power. Moreover, the power granted to Babylon made her arrogant, and in subsequent

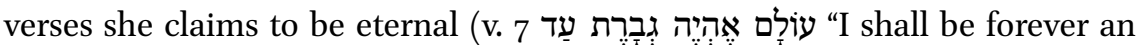

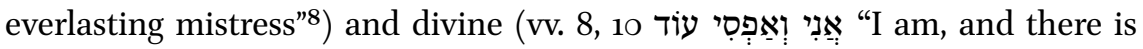
no one besides me"9). Now queen Babylon must face judgment for her hubris and merciless treatment of the Judahites. According to Baltzer, the indictment

standard text simply cannot follow one and the same manuscript due to the poor preservation of the extant sources; Abusch, Magical Ceremony Maqlû, 281. For a synoptic overview of the Maqlû lines quoted in this study and their transliteration, I would like to refer the reader to Parts I-II of the aforementioned text-critical edition.

8 Following the critical apparatus, I read גָרברָּרת עַד in Codex Leningradensis as a genitival phrase: גבר עדת עד; cf. GKC, §94g. For a discussion on the syntax of this verse and the interpre-

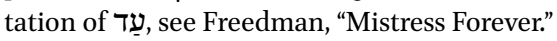

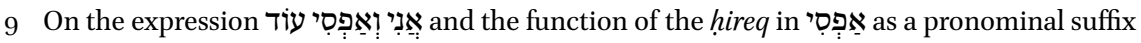
rather than hireq compaginis, see Joüon, §16on; cf. GKC, §9ol. We find this expression also in Zeph 2:15a, where the city of Nineveh is portrayed in identical metaphorical language as in

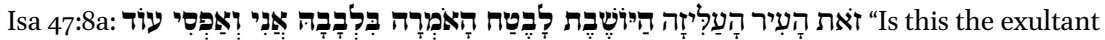
city that lived securely, saying to herself: I am, and there is no one besides me?" Sommer regards Isa 47:5-11 as a reprediction of Zeph 2:13-15: the composer adopted the Zephaniah passage and changed the historical referent; Sommer, "Allusions and Illusions," 172 n. 32. 
against Babylon and her subsequent punishment belong to the "lawcourt scenes" in Deutero-Isaiah. ${ }^{10}$ Interestingly, legal imagery is also found in Maqlû. ${ }^{11}$ The victim requests a court hearing, ${ }^{12}$ and the effigy of the witch has to stand trial (Maqlû V 23-24):

\section{lillu lībilma kaššāpta ana dayyāniša dayyānša kìma nēši lissâ eliša}

May an idiot bring the witch to her judge, And ${ }^{13}$ may her judge roar at her like a lion.

In Maqlû I 73-121, the incantation that centres on the judgment and the execution of the witch, the fire-god Nuska is called upon to identify the witch, whose identity is unknown to the victim, and to establish the criminal nature of her deeds. The witch's execution - death by fire-is subsequently carried out by Girra, another fire-god, who is often associated with Nuska due to their overlapping roles. As observed by Abusch, the witch has broken the social contract, the set of rules which form the foundation of human society and the whole, universal community of the living and the dead..$^{14}$ The witch thus poses a threat to society, and the punishment for transgressing the agreement is total destruction. We can infer from Isa 47 that Babylon was also under obligation as the agent of God's judgment of his people, but she broke the terms of agreement with her cruel and arrogant behaviour and now she must stand trial.

2.1

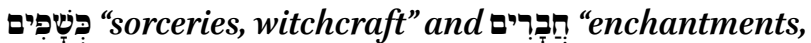
spells" $(v v .9,12)$

We read in Isa 47:9a that Babylon will suffer loss of children and widowhood as a punishment for her misbehaviour. The verse continues as follows:

10 Baltzer (Deutero-Isaiah, 16-17) also mentions Isa 41:1-5a, 21-29; 43:8-15, 22-28; 44:6-8; 48:1-11; 49:14-16; 52:13-53:12.

11 On the legal context of Maqlûu, see Abusch, "Socio-Religious Framework, Part I," 22-32.

12 E.g., I 68-71; I 114; II 108; II 130; II 145.

13 Abusch (Magical Ceremony Maqlû, 33o) suggests as an alternative translation: "So that her judge may ...."

14 Abusch, "Socio-Religious Framework, Part I," 31-32. 


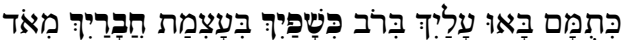

in full measure they ${ }^{15}$ will come upon you, in spite of ${ }^{16}$ the multitude of your sorceries, in spite of the great power of your enchantments.

In v. 12a Babylon is addressed in similar terms:

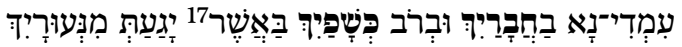

Stand fast in your enchantments and in the multitude of your sorceries, with which you have laboured from your youth.

The noun * כֶּשֶׁ is only attested in the plural form in the Hebrew Bible. ${ }^{18}$ It is a derivative from the equally scarce verbal root $\sqrt{ } \sqrt{19}$, the meaning of which is still subject of debate. ${ }^{20}$ Modern scholarship traces the etymology of this root back to the Akkadian verb kašāpu "to bewitch, to cast an evil spell."21 The noun *כָּשֶׁ may be derived from Akkadian kišpū "sorcery, witchcraft,"22 a plurale tantum which is widely attested in Maqlû and other Mesopotamian antiwitchcraft materials as a term for malevolent magic. See for example Maqlû I 126-127:

15 I.e., loss of children and widowhood.

16 The preposition בִ can mean "in spite of", e.g., Num 14:11; Isa 16:14; Ps 27:3; cf. BDB, 9ob; HALOT, s.v. I בְ.

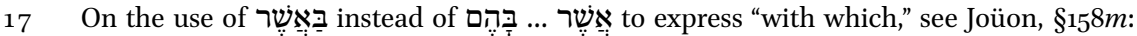
"Sometimes, by a kind of anticipation, אשר בשר is preceded by אשר of the accusative or by a preposition, which logically should follow in the relative clause, prefixed to a pronominal suffix referring to the implicit antecedent"; cf. GKC, §138f.

18 In addition to Isa 47:9, 12, we find it in 2 Kgs 9:22; Mic 5:11; Nah 3:4.

19 Exod 7:11; 22:17; Deut 18:10; Mal 3:5; Dan 2:2; 2 Chr 33:6.

20 On the meaning and possible etymology of כשרף, see Jeffers, Magic and Divination, 65-70; cf. Kabamba Kiboko, Divining the Woman of Endor, 160-165. Both authors question the derogatory meaning of the root and its derivatives.

$21 C A D, 8: 284 a ;$ cf. BDB, 506b; HALOT, s.v. כשף.

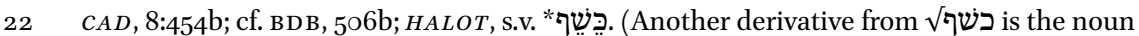

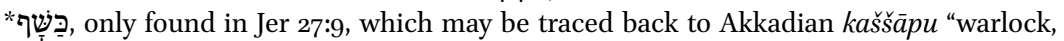
sorcerer" [fem. kašs̄āptu "witch, sorceress"]; cAD, 8:291a-292a; cf. вDB, 506b; HALOT, s.v.

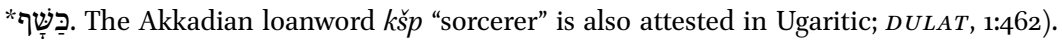
However, for a critical analysis of the Akkadian loan hypothesis, see Mankowski, Akkadian Loanwords in Biblical Hebrew, 74-75. 


\section{kaššāpu ikšipanni kišpī ikšipanni kišipšu \\ kaššāptu takšipanni kišpī takšipanni kišipši}

A warlock has bewitched me; bewitch him with the witchcraft with which he bewitched me

A witch has bewitched me; bewitch her with the witchcraft with which she bewitched me

Although queen Babylon is not explicitly denounced as a witch or sorceress in

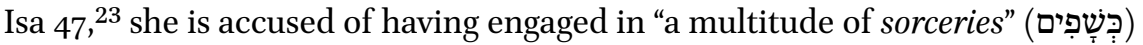
since her youth. Deutero-Isaiah does not elaborate on the exact nature of Babylon's malicious acts; ${ }^{24}$ he solely emphasizes the longevity and high fre-

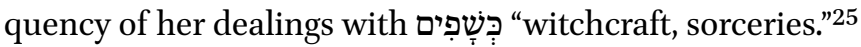

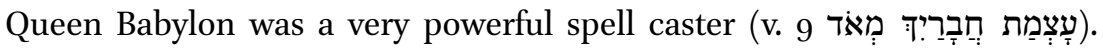
Interestingly, the segolate noun חֶֶֶ bears two seemingly different meanings: "company, association" on the one hand, and "spell, enchantment" on the other. ${ }^{26}$ When we look at the verbal root $\sqrt{ }$, we see the same semantic differences. In the qal חבר means "to join, ally oneself, be joined," which is a common meaning for *hbr in Semitic, but it is also used as a magical term, "to charm, cast spells," albeit rarely (Deut 18:11 and Ps 58:6 [Eng. 58:5]). ${ }^{27}$ As observed by Finkelstein,

23 Notwithstanding the disputed meaning and origin of the terms in Biblical Hebrew, nei-

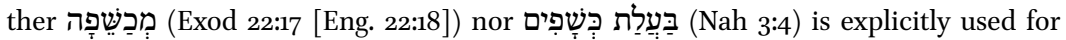
queen Babylon.

24 The Hebrew Bible in general does not elaborate on the exact nature of magical practices or on the various types of diviners, which could be explained by the polemical stance

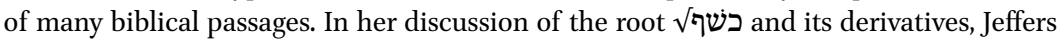
observes the following: "Little is shown by these texts except that the practitioners of kšp are described in an increasingly derogatory fashion, where their original function seems to have been forgotten" (Magic and Divination, 68).

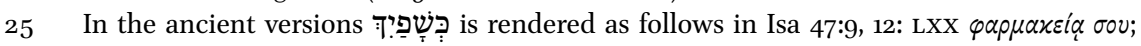

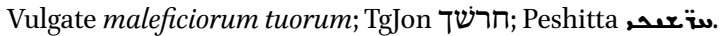

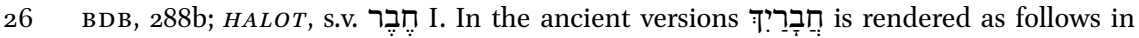

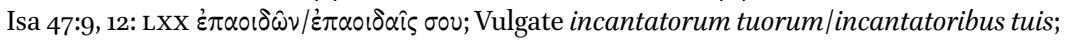

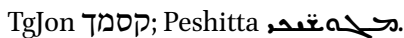

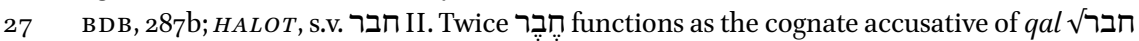

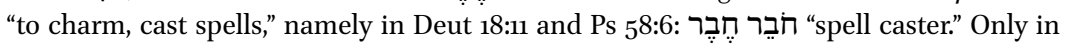
Isa 47:9, 12 the noun is used on its own in the sense of "enchantment, spell." Note also the attestation of $h b r$ "exorcist, spell-caster" in Ugaritic; DULAT, 1:348; Smith, "Magic of Kothar." 
In the understandable attempt to reconcile all occurrences of the stem with the basic meaning of "to tie, bind, etc.," the hōberr heber has been connected with the magical practice of the tying of knots, which is well attested in ancient Near Eastern religions. Others have seen in it rather an extension of the literal meaning "to bind" to the realm of speech; the reference would then be to one who combines words together in artful ways in casting a spell, a spellbinder. ${ }^{28}$

These interpretations are supported by the Akkadian cognate ubburu "to bind" (*hbr), which is also used to convey magical binding, of which we find evidence in Maqlû. ${ }^{29}$ However, Finkelstein derived the meaning of חבקבר חקבר from the root sense of the Akkadian verb habāru "to be noisy, make noise" instead. ${ }^{30}$ Because of the merger of the phonemes $/ h /$ and $/ h /$ in Hebrew, the verbal root חבר could go back to etymological *hbr rather than *hbr when used in a divinatory context. In that case, the חזבר חקֶבר does not cast spells through the act of binding, as in sympathetic magic, but through the act of speech, by making a sound. Due to the lack of a clear etymology and the few biblical attestations of the terms, the exact activity of the חבבר חקבר remains unknown. ${ }^{31}$ We seem to be dealing with a practitioner, male or female, who would cast spells either through some sort of binding magic or through the power of speech. In Maqlû the witch is also accused of casting spells. See for example Maqlû I 27 (cf. V 140):

\section{tûša ša kaššāpti lemutte}

Her spell being that of an evil witch ${ }^{32}$

In the above example the Akkadian term tû "incantation, spell" is used in the context of black magic. ${ }^{33}$ In contrast to the noun * parallels between in Isa 47:9, 12 and the terminology used in Maqlû for denoting spells (and counter spells). ${ }^{34}$

28 Finkelstein, "Hebrew חבר and Semitic *hbr," 328.

$29 C A D, 20: 12 b$. See for instance, Maqlî III 109 where the witch is addressed as follows: attīe ša tubbirīnni "O you who have bound me"; cf. II 95; VII 6o.

$30 \quad$ Cf. $C A D, 6: 7 \mathrm{~b}$.

31 For further discussion, see Jeffers, Magic and Divination, 31-35; cf. Kabamba Kiboko, Divining the Woman of Endor, 165-167.

32 For a discussion on whether witches were regarded as evil per se, see Abusch, "Demonic Image," 32-34.

33 In addition to tûu, we find tuduqqû (II 158) and šiptu (II 157; VII 26; VII 32; VII 41; VII 44; RT 95, 173).

34 However, as seen above, there may be an etymological link between ubburu "to bind (magically)," which is attested in Maqlû (cf. n. 29). For further discussion 


\section{2} $\sqrt{7}$ "to bewitch away" and $\sqrt{7}$ "to ward off" (v. 11)

In v. 11a we find terminology that could be magical in nature:

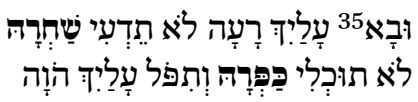

Evil shall come upon you, which you do not know how to bewitch away disaster shall fall upon you, which you will not be able to ward off

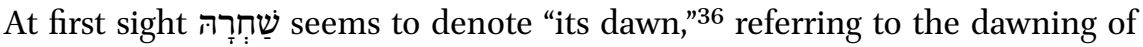
evil. ${ }^{37}$ When taking the poetic structure of v. 11a into account, the form שֶחְרָה might rather be construed as an infinitive construct with 3 fsg object suffix, par-

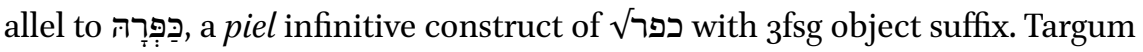
לא תידעין למבעי Jonathan to Isaiah interprets the form exactly as such and reads you will not know how to pray it away." In a similar vein, the $B H S$ appa-

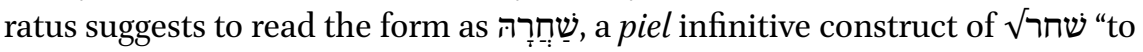
seek, beseech" (used here in the sense of "to pray"). However, the etymology and meaning of the root are still subject of debate. Perhaps שחר goes back to a root cognate to Akkadian sahāru "to turn (around), encircle,"38 which is also used in the sense of "to seek, beseech" 39 and even in the magical sense of evil that is surrounding a person, i.e., "to bewitch, enchant."40 The verb sahāru is attested in Maqlû III 120 (cf. II 199):

on the verb roots כשר בשר and their correspondence, both etymologically and semantically, to the Akkadian verbs kašāpu and ubburu, see Held, "Studies in Biblical Lexicography," 78-79; cf. Smith, "Magic of Kothar," 379 and n. 11.

351 1QIsa ${ }^{a}$ reads ובאה, which solves the gender disagreement between the subject and the verb. On this type of disagreement, see Joüon, §15oj.

36 Syntactically, the absence of the object marker before שִָׁ would not be a complicating factor due to the lack of prosaic features in Biblical Hebrew poetry.

37 Cf. Vulgate veniet super te malum et nescies ortum eius "evil will come upon you, and you

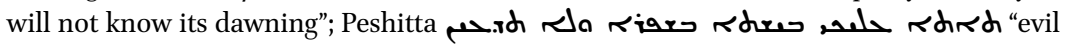
will come upon you at dawn and you will not know." The LXX, by contrast, seems to read

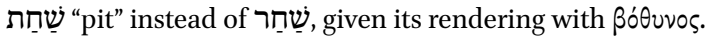

38 HALOT, s.v. שחר II and שחר III. The shift from etymological $/ h /$ to $/ h /$ can be explained by the merger of $|h|$ with $|h|$ in Hebrew, and the sound change of $|\check{s}|$ to $/ \mathrm{s} /$ has been attested in Neo-Assyrian; see Luukko, Grammatical Variation, 74-75 (I am grateful to the anonymous reviewer for calling my attention to this publication).

$39 \quad C A D, 15: 37$ b, especially 41 a, s.v. 2.

$40 \quad C A D, 15: 37$ b, especially $46 \mathrm{a}$, s.v. 3 d; cf. the Arabic verb sahara "to bewitch, enchant" and its derivative sāhir "sorcerer." For further discussion, see Jeffers, Magic and Divination, 116-117; Vanderhooft, Neo-Babylonian Empire, 185-186. 
ana sāhnerti suhrīma iqbû

Has said 41 "enchant" to an enchantress

In the example above the root sahāru is clearly used in the context of black magic, and we may thus have stumbled upon another linguistic parallel between Isa 47 and Maqlî. ${ }^{42}$

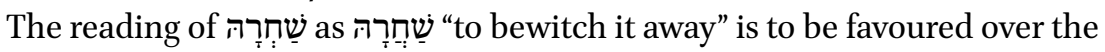
emendation in BDB, which proposes שָׁחָדָ "to buy it off," a qal infinitive construct of שִחְרָרה was a scribal error for 7 . Despite all her riches and luxuries, queen Babylon will be unable to bribe off the evil that is about to strike her. However, the read-

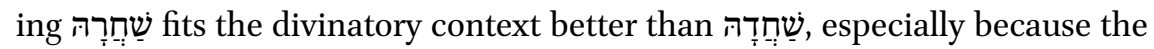
following infinitive construct, as well.

The piel of כפר $\sqrt{ }$ has traditionally been understood as "to cover, atone," which does not fit the context of our verse. ${ }^{44}$ However, in his in-depth study on the usage of כפר in the Hebrew Bible and in cognate Semitic languages, Levine convincingly argued that the meaning of כפר in Biblical Hebrew closely parallels the Akkadian verb kapāru "to wipe off," which also denotes "to purify magically." 45 Following Levine's hypothesis, the verb כפר refers in our verse to an act of magical character: Babylon is unable to avert disaster through magical means.

$41 \quad$ I.e., the witch has said (to her companion).

42 In my discussion of סִחרִ in v. 15 I will come back to sāhnertu "enchantress, sorceress," the substantivized feminine participle of the same verb, and its masculine equivalent sāhiru "enchanter, sorcerer."

43 вDB, 1005a.

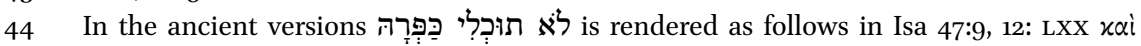

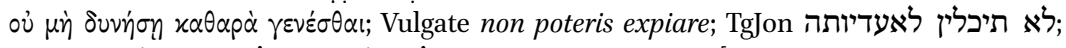

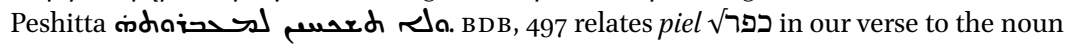
כּפֶר "bribe, ransom." Babylon will be unable to propitiate the upcoming disaster by pay-

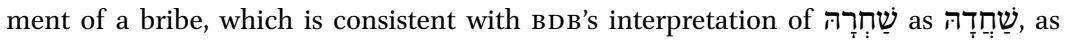
seen above.

45 Levine, In the Presence of the Lord, 55-63, 123-127. For further examples in Akkadian, see $C A D, 8: 179$ b, s.v. 3 d. There are no attestations of the magical usage of the verb kapāru in Maqlû. 


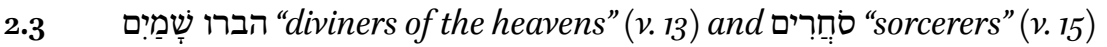
In the final verses of this chapter Deutero-Isaiah addresses the fate of the partners in crime of sorceress Babylon, who have accompanied her from her youth. In v. 13b we read about a certain class of diviners:

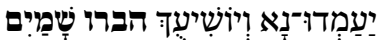

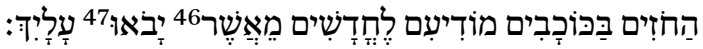

Let the [?] of the heavens stand up and save you, those who gaze at the stars, who declare each new moon what will befall you.

We are dealing here with a ketiv/qere issue:הברְרי הברו, a phould be read asticiple construct of the hapax verb הבר הבר ה habara "to cut (to pieces)."48 In that case we can understand הבְרֵי שָׁמַיְם as as "the ones who divide the heavens," i.e., they divide the sky into segments, or "houses." 49 The rest of v. 13b also seems to refer to these Babylonian specialists who deal with all sorts of astrological matters: they are stargazers, and new moon after new moon they give celestial forecasts concerning matters of state. We may thus be dealing here with a class of palace scholars who interpreted celestial omens and advised queen Babylon accordingly.

Instead of the ketiv הברו 1QIsa ${ }^{a}$ reads חוברי, the root of which (חבר ) can mean "to charm, cast spells," as seen above. We encountered its derivative, חַברברִ "enchantments, spells," in vv. 9 and 12. The reading חוברי שמים in 1QIsa can thus be understood as "conjurers of the heavens." If If the root חבר related to Akkadian ubburu "to bind (magically)," we may have stumbled upon

46 The $B H S$ apparatus suggests to read of the letter mem at the end of the preceding word. For further discussion, see Goldingay and Payne, Isaiah 40-55, 2:111.

47 The LXX, Peshitta, Targum, and 1QIsa ${ }^{a}$ read the form as the singular יבוז instead.

$48 H A L O T$, s.v. הבר. BDB, 211a is doubtful about the cognate evidence from Arabic ("text prob. corrupt"). See also Blau's critique of this hypothesis; instead, he proposes a link between הבר and the Ugaritic verb hbr "to bow," used in Isa 47:13 in the sense of "to worship," i.e., "those who worship the heavens" (Blau, "Hōborē Šāmājim," 183-184); cf. Ullendorff, "Ugaritic Marginalia II," 339-340.

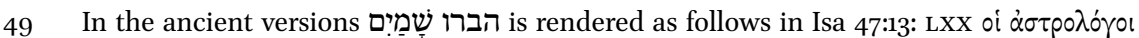
שלט.

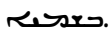

50 Following the variant reading in 1 QIsa ${ }^{a}$, Held proposes to emend the ketiv הברי to

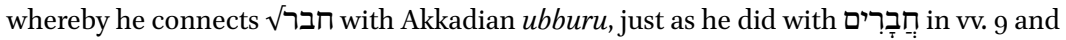
12 (cf. n. 34); Held, "Studies in Biblical Lexicography," 78-79. 
another case of lexical affinity between Isa 47 and Maqlû, because $u b b u r u$ is repeatedly employed in the latter source. ${ }^{51}$ However, although חוברי is an interesting variant, which fits well into the magical context of this Isaianic passage, it is unclear what type of magic the "conjurers of the heavens" are involved in. In what sense are they casting a spell on the heavens? Could the phrase hint at the invocation of astral deities, of which we find evidence in Maqlût? ${ }^{52}$

An alternative reading of the ketiv betrays an even more intriguing lexical parallel with Maqlû. Several scholars favour the emendation of ברי to explaining the latter form as a Hebraized loan from the Akkadian root barû "to look upon, check," which is also used in a divinatory and revelatory sense, ${ }^{53}$ or from the substantivized participle bāru "diviner" (f. bārītu). ${ }^{54}$ The term bārû was used for the learned specialist, and although a $b \bar{a} r \hat{u}$ usually performed extispicy, libanomancy, or lecanomancy, in the Neo-Assyrian period he may have also been associated with the study of celestial omens. ${ }^{55}$ Interestingly, in a variant reading of Maqlû III 45 the witch is called bāritu ša müši "diviner of the night" instead of bayyārtu ša mūši "huntress of the night." ${ }^{56}$ Hence, this variant reading in Maqlû refers to the bāritu "female diviner" in a sinister context and possibly alludes to the witch's performance of black astral magic. Night time was considered to be a favourable time for the witch because at night she could invoke the astral deities for her evil rituals. In Maqlû IV 52-6o reference is made to the witch's performance of Zikurrudâ ("cutting-of-thethroat") magic in the presence of the moon, Jupiter, Cygnus, Lyra, Leo, Ursa Major, Scorpio, Orion, and Centaurus, respectively. According to Schwemer

Entries in the older Diagnostic Handbook show that the calendrical date at which "cutting-of-the-throat" had been carried out was regarded as significant. According to a few texts, the symbolic killing of the patient by zikurudû is achieved by pouring water as a funerary offering at the time when a "star" (planet or constellation) sets and thus, according to Mesopotamian cosmology, enters the underworld. An anonymous

$51 \quad$ Cf. n. 29.

$5^{2}$ In the following I will discuss this Mesopotamian witchcraft concept in more detail.

$53 \quad C A D, 2: 115$ a.

54 The Akkadian loan hypothesis is suggested in Morgenstern, "Message of Deutero-Isaiah," (1958), 39, 57 n. 45; (1959), 18; Schrader (ed. Zimmern and Winckler), Keilinschriften und

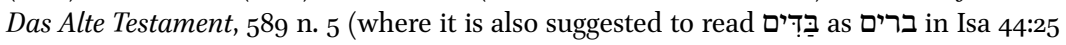
and Jer 5o:36); Vanderhooft, Neo-Babylonian Empire, 183 n. 229; Zimmern, Akkadische Fremdwörter, 67 .

55 See Reiner, Astral Magic in Babylonia, 65.

$5^{6}$ The variant is found in W 23298/1 from Uruk (Iraq Museum, Baghdad); for a synoptic overview of Maqlû III 45, see Abusch, Magical Ceremony Maqlû, 88. 
Neo-Assyrian letter that makes accusations against a family in the city of Guzana and states that "their women bring down the moon from the sky" may well refer to the same concept. ${ }^{57}$

Schwemer further discusses the importance of the day of the new moon for Mesopotamian anti-witchcraft rituals. ${ }^{58}$ It seems to have been an auspicious time for rituals combatting the witch and her witchcraft. ${ }^{9}$ Perhaps because the witch was thought to be less powerful when the moon was absent, her craft being dependent on the invocation of astral deities. Alternatively, the new moon may have been the most suitable time for sending the witch to the netherworld because at that time the veil between the earthly and the lower world was lifted, as evidenced by the funerary offerings made during the new moon. Therefore, according to Mesopotamian magico-religious thought, the witch used her knowledge of celestial phenomena for sinister purposes, and

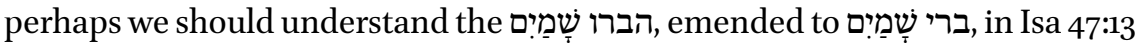
in a similar vein. They are the evil companions of sorceress Babylon who help her to inflict harm on her victims with their understanding of the astral bodies in the night sky. In addition, the reference to the new moon in the final

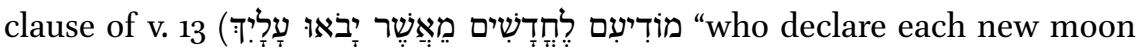
what will befall you") may be better understood if we take the importance of ברי The new moon in the Mesopotamian witchcraft concept into account. The שַָׁמיִם forewarn sorceress Babylon of any counter-attacks that will be performed against her during the new moon, so she will be able to ward them off.

Interestingly, the negative view of these long-time companions of sorceress Babylon is emphasized in v. 15:

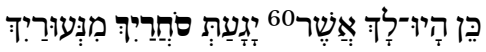

Such to you are those with whom you have laboured, your sorcerers from your youth

Deutero-Isaiah refers here to the סחיררים as "sorcerers." At first glance,

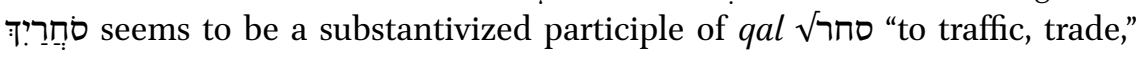

57 Schwemer, "Mesopotamia," 46-47.

58 Schwemer, "Evil Witches," 180.

59 Cf. Maqlû VI 118 [pațrū kišpū] ki ina ūm(?) bubbuli pašrū ruhêki "[Undone is] your [witchcraft], on the day of the disappearance of the moon your spittle is released."

6o The BHS apparatus suggests to read בַּ "with whom" (cf. Peshitta, TgJon, and the Vulgate); see also n. 17 . 


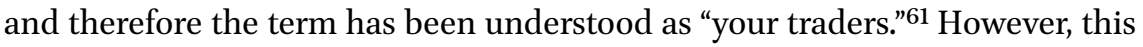
interpretation does not fit the context, and it is now commonly accepted to relate $\sqrt{ }$ in this verse to Akkadian sahăru, which can be used in the sense of "to bewitch, enchant," as already observed in our discussion on the meaning of שִ in v. ${ }^{11.62}$ Crucially, the verb sahăru is also attested in Maqlû I 77 in the form of the substantivized participles sāhiru "sorcerer, enchanter" and sāhertu "sorceress, enchantress" (cf. II 41; III 120, 129):

\section{șalmū sāhiriya u sāhnertiya ${ }^{63}$}

The figurines of my enchanter and my enchantress

Our overview has thus revealed a significant, shared overlap in magical and divinatory terminology between Isa 47 and Maqlû. Deutero-Isaiah may not have been aware of the exact nuances of the Akkadian terms to which he was exposed, but the fact that his choice of vocabulary is mirrored in Maqlu is intriguing.

\section{Gender-Stereotype}

Our analysis of the magical and divinatory terminology in Isa 47 further revealed a marked emphasis on Babylon as the female agent of evil. Granted, her male companions are briefly mentioned towards the end of the chapter (vv. 13, 15), but only in close association with sorceress Babylon, who is seen as the main perpetrator. The depiction of a city as a woman or even as a witch is attested elsewhere in the Hebrew Bible ${ }^{64}$ but the extent to which the

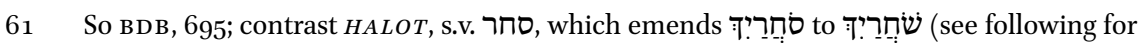

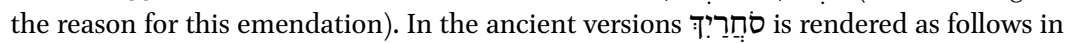

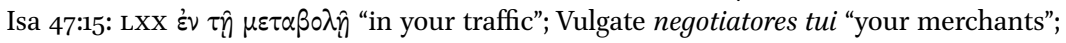

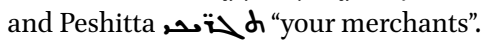

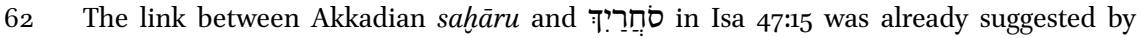
Driver, "Linguistic and Textual Problems," 400-401. Duhm, Das Buch Jesaia, 328, also inter-

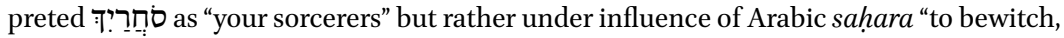
enchant." Further on סחירריָּ, see Held, "Studies in Biblical Lexicography," 79; Jeffers, Magic and Divination, 116-117.

63 For other, non-substantivized forms of the verb sahāru in Maqlû, see II 199 and III 120.

64 On the personification of cities as women, see n. 2. In Nah 3:4 the city of Nineveh is

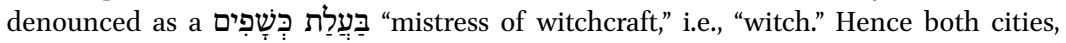
Nineveh and Babylonia, which represent the Neo-Assyrian and the Neo-Babylonian empires respectively, are associated with witchcraft in the Latter Prophets. Hamori 
Babylonians and their magical practices are femininized in Isa 47 is striking and begs the question whether this female personification (and defamation) may have been influenced by the female stereotype and the bland portrayal of the witch's male companions in the Mesopotamian anti-witchcraft corpus. Although Maqlû refers to both male and female agents of evil, and they are often paired together, ${ }^{65}$ the witch is usually depicted as a dangerous woman and described in much greater detail than her male counterpart, who is mostly a "formulaic companion" to the witch. ${ }^{66}$

Rollin suggests that the patrilineal societal structure may have contributed to the stereotypical portrayal of the female witch in Mesopotamia. ${ }^{67} \mathrm{~A}$ woman would have usually been brought into her husband's household, where she would have been viewed with suspicion as an outsider with divided loyalties, thus making her an easy scapegoat if misfortune struck. Alternatively, according to Abusch, the stereotyped picture of the female witch is the result of the gradual demonization of the witch in the historical development of Mesopotamian witchcraft conceptions. ${ }^{68}$ When witchcraft beliefs were still rooted in the popular sphere, the witch was not necessarily an agent of evil; (s)he could also take on the role of a "white" witch. However, at some point, Abusch suggests the early second millennium BCE, popular witchcraft beliefs were integrated into normative Mesopotamian religion and underwent change. The witch was transformed into a supernatural demonic force and became the opponent of the ăšipu, which may have caused or intensified the male-female antagonism.

mentions Isa 47 and Nah 3:4 in her discussion of the literary "witch and whore" trope in the Bible; Women's Divination, 212.

65 See for instance, Maqlû I 73-86; II 39-5o. Maqlû III 165 even refers to the witch's clique: lispuh illatkunu mār ${ }^{d E a}$ mašmaššu "May the son of Ea, the exorcist, scatter your cohort"; cf. Abusch, "Demonic Image," 31.

66 Thus Schwemer, "Mesopotamia," 49. Further on the stereotype of the female witch in the Mesopotamian anti-witchcraft corpus, see Rollin, "Women and Witchcraft"; Sefati and Klein, "Role of Women"; in relation to the portrait of the female witch in the Bible, see Hamori, Women's Divination, 210-211. On the gendered stereotypes in later Judaism, Christianity, and Greco-Roman culture, see Stratton and Kalleres, Daughters of Hecate.

67 Rollin, "Women and Witchcraft," 43-44.

68 On the conceptual development of witches and witchcraft in Mesopotamia, see Abusch, "Considerations"; idem, "Demonic Image." See further Van Buylaere, "Decline of Female Professionals." 


\section{$4 \quad$ Vengeance and Reversal of Fate}

The themes of vengeance and reversal of fate feature prominently in Maqlû. 69 Because the identity of the witch is usually unknown to her victim and the $\bar{a}$ šipu, ${ }^{70}$ the defensive counter-rituals consist of a symbolic reversal through which the ill-health and misfortune that the witch inflicted on her victim are brought upon herself. See for instance Maqlû II 90-97:

d [G]irra šurbû ilu ellu

enenna ina mahar ilūtika rabūti

šinā șalmī kaššāpi u kaššāpti ša siparri ēpuš qātukka

maharka uggeršunūtima kâša apqidk[a]

šunu limūtūma anāku lublut

šunu lìtebbirūma anāku lūšir

šunu liqtûma anāku lumìd

šunu līnišūma anāku ludnin

Grand Girra, pure god,

Now in the presence of your great godhead

Two bronze figurines of the warlock and the witch I have fashioned with your power.

In your presence I cross them, and to you I hand them over.

May they die, but I live

May they be bound, but I be acquitted,

May they come to an end, but I increase,

May they weaken, but I become strong.

See also Maqlû VII $69-71:^{71}$

ipšu tēpušinni ēpuški

miȟr tušamhirīnni ušamherki

gimil tagmilīnni utēr agmilki

The sorcery that you have performed against me I perform against you,

The (ominous) encounter that you have caused me to encounter I make you take over,

The vengeance that you have wreaked on me I wreak back on you.

69 Schwemer, "Mesopotamia," 49; cf. Abusch, Witchcraft Series Maqlû, 26-27.

70 On the anonymity of the witch, see Maqlû I 87; II 205; II 208; IV 3.

71 Cf. Maqlû III 59-6o; III 72-73; III 92-97; v 5-8; v 57-75; VII 55-78; VII 100. 
In Isa 47:3b we read about God's vengeance being wreaked on sorceress

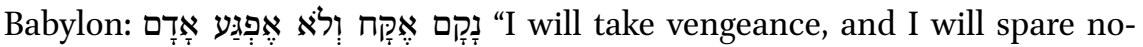
one."72 The punishment is the same which Babylon once bestowed upon the Judahites: exile (v. 2), slavery (v. 2), (sexual?) humiliation (v. 3a), loss of children (v. 9), and widowhood (v. 9). The reversal of fortune becomes even more apparent if we take the Zion texts in Deutero-Isaiah into account (Isa 49, 51, and 54). In a sense, we can regard lady Zion as the victim of sorceress Babylon. Zion will be restored to her former glory, whereas Babylon faces ruin and destruction, experiencing the same misfortune which she had once inflicted on Zion. Franke has extensively studied the theme of the reversals of fortune in the Book of Isaiah, and regarding our chapter he observes:

Chapter 47 is the key to the reversal of fortune of Daughter Zion. It functions as a pivot for Second Isaiah in that it is the point in the book where Judah/Israel changes places with the oppressor, Babylon. In ch. 47 Babylon descends into darkness, loses power and status, is clothed like a slave, has no hope for salvation, and now becomes the oppressed. ${ }^{73}$

The reversal of fortune, which is such a key theme in Deutero-Isaiah, is even better understood if we take Mesopotamian ideas about counter-witchcraft into consideration. The reversal of the victim's and the witch's fate, which features prominently in Maqlû, is mirrored in the downfall of sorceress Babylon and the salvation of her victim, lady Zion.

In v. 14 sorceress Babylon is told about the dire fate of the "diviners of the heavens," who are denounced as "sorcerers" in the final verse, as noted above:

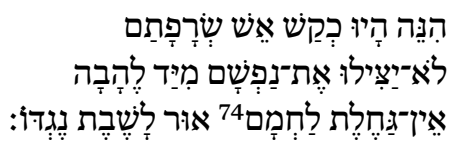

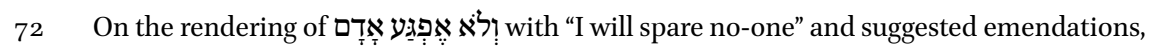
see HALOT, S.v. פגע; cf. Blenkinsopp, Isaiah 40-55, 277; Goldingay and Payne, Isaiah 40-55, 2:98.

73 Franke, "Reversals of Fortune," 119-120.

74 On the peculiar vocalization of the qal infinitive construct of ל לחם "to be, become warm," see GKC, §28b. 
See, they have become like stubble, the fire consumes them; they cannot deliver themselves from the power of the flame. No coal for warming oneself [is this], no fire to sit before!

The fire could refer to a situation of warfare and reprisal against Babylon. The city will be destroyed by fire just like Zion had once fallen victim to the flames, in keeping with the theme of the reversals of fortune. ${ }^{75}$ Alternatively, v. 14 could hint at the ritual burning and destruction of the witch's companions, which is the central theme in Maqlû: the figurines of the witch and her warlock are burned in a ritual fire through the invocation of the fire-god Girra. The witch's body has to be completely destroyed, thus denying her a proper burial and the chance for her ghost to enter the netherworld. See for instance Maqlû I 115-116:

qumu kaššāpī u kaššāptī

akul ayyābìya aruh lemnūtīya

Burn my warlock and my witch,

Devour my enemies, consume the ones who would do evil to me!

See also Maqlû I 140-142: ${ }^{76}$

hū $\bar{a} z \bar{u} b \bar{a}$ u itattukā

quturkunu litelli šamê

la'mīkunu liballi dŠamši

Melt, dissolve, drip ever away!

May your smoke rise ever heavenward,

May the sun extinguish your embers.

According to Abusch, the total destruction of the witch through burning, whereby she is kept out of the netherworld, is probably the oldest Mesopotamian way of punishing the witch. This original treatment of the witch, which is already documented in the Old Babylonian period, is characteristic for Maqlû. In a secondary conceptual development, the old witchcraft materials were transformed, and the witch was burned and conveyed to the netherworld,

75 From a historical perspective, Babylon never went up in fire and flames when it fell into Achaemenid hands in 539 BCE. According to the Cyrus cylinder, the conquest of Babylon happened peacefully.

76 Cf. Maqlû I 135; II 15-16; II 71; II 147-148; II 191; II 218-224; III 22-24; IV 140-146. 
where she became a demonic force kept under control by the āšipu. ${ }^{77}$ Thus, although the motif of the witch's presence in the netherworld is absent in Maqlî, ${ }^{78}$ there are attestations of this secondary concept elsewhere in the Mesopotamian anti-witchcraft corpus. ${ }^{79}$

Interestingly, Deutero-Isaiah may have incorporated references to sorceress Babylon's dwelling in the netherworld in Isa 47. Some discrepancy is noticeable among scholars in their interpretation of Babylon's dire fate in the first half of Isa 47: she will either be subjected to exile and enslavement, ${ }^{80}$ or descends into the underworld where she languishes in darkness. ${ }^{81}$ The latter interpretation

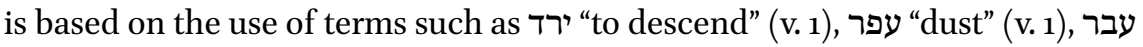
נהרות "to wade through rivers" (v. 2), דומם "silence" (v. 5), and חשך "darkness" (v. 5), which are characteristic for biblical and Ancient Near Eastern descriptions of the underworld. ${ }^{82}$ If Isa 47 indeed hints at sorceress Babylon's conveyance to the netherworld, we may have stumbled upon an additional thematic overlap between Isa 47 and Mesopotamian witchcraft beliefs.

\section{$6 \quad$ Concluding Observations}

Other scholars have also noticed similarities between the Hebrew Bible and Maqlû. ${ }^{83}$ Especially Ezek 13:17-23 has been linked to Maqlû. Ezekiel's diatribe against the false female prophets is preserved in a highly complex text, riddled

77 Abusch, "Considerations."

78 See for instance Maqlû VIII 123: [ ${ }^{\mathrm{d} E r e] s ̌ s}[k] i g a[l]$ ana erșeti ayy-uš $[\bar{e}] r[i d k i]$ "May [Ere]škigal not permit [you to go] down into the netherworld."

79 For examples and further discussion, see Abusch, "Considerations," 6gff; idem, "SocioReligious Framework, Part I."

8o See for example Blenkinsopp, Isaiah 40-55, 280-281; Vanderhooft, Neo-Babylonian Empire, $181-182$.

81 See Baltzer, Deutero-Isaiah, 270-271 (and throughout the rest of his commentary on this chapter); Franke, "Reversals of Fortune", 110-113.

82 For biblical and extra-biblical references, see the sources mentioned in the previous footnote.

83 Jeffers ("Wicked Witches") discusses the concept of space in the Deuteronomistic History in relation to the Maqlû ritual, without suggesting a direct link between both sources. Jeffers further suggests that some of the imagery in Zech 5:5-11, which describes the prophet's vision of a woman in a basket, may pertain to the Maqlû ritual; private communication dated September 6, 2020. Hamori (Women's Divination, 207-208) finds the portrayal of the dangerous woman in Prov 7 , who preys on men and seduces them, reminiscent of Maqlû III 1-12. She does not propose a direct link between the two sources, but regards the similar imagery as proof that the literary trope of the spiritually and sexually dangerous woman was very common and widespread. 
with text-critical issues and hapaxes. The prophet accuses the women of hunting and entrapping souls and manipulating life and death. It was Herrmann who in his Ezekiel commentary from 1924 explicitly linked this passage with the binding magic (kasû) mentioned in Maqlû. ${ }^{84}$ Many scholars have since adopted Herrmann's thesis and regard the women in Ezek 13:17-23 as witches who use binding magic to control and possibly kill people. ${ }^{85}$ This passage in Ezekiel is particularly important for the present study because scholars have discussed the ways in which Ezekiel, whose prophetic activity seems to have taken place in Babylonia in the first half of the sixth century BCE, could have known about Maqlû. ${ }^{86}$ Stökl argues that Ezekiel's knowledge of Maqlû could be the result of his upper level training in a cuneiform scribal school, rather than through observance of the ritual or hearing about it from someone with inside knowledge. ${ }^{87}$ Nevader questions Stökl's thesis, stating that it would have been very unlikely for an exile to receive the highest possible level of education. Instead, she emphasizes the domestic setting of Maqlû and suggests that Ezekiel may have witnessed the actual ritual. ${ }^{88}$

The aforementioned views are relevant for our topic because DeuteroIsaiah's situation seems to have been similar to that of Ezekiel. They were both living in Judean communities in sixth-century вСЕ Babylonia, and their work shows clear evidence of acculturation given the frequent Akkadian loanwords and references to local beliefs and practices. ${ }^{89} \mathrm{I}$ am hesitant, though, to state that Deutero-Isaiah had direct access to Maqlûu, either in text-form or by

84 Herrmann, Ezechiel, 86. For more recent discussions on the parallels between Ezek 13:1723 and Maqlû, see Bowen, "Daughters of your People," 421-422; Korpel, "Avian Spirits," 105; Stökl, "Schoolboy Ezekiel," 58-59.

85 For a comprehensive overview (and criticism) of this interpretation of Ezek 13:17-23, see Evans, "Death-dealing Witchcraft."

86 On the re-emerged scholarly consensus regarding the date and location of Ezekiel's ministry, see Vanderhooft, "Ezekiel in and on Babylon," 100-101. For a discussion on the incorporation of Mesopotamian lore in the Book of Ezekiel, see Nissinen, "(How) Does the Book of Ezekiel"; Winitzer, "Assyriology and Jewish Studies in Tel Aviv."

87 Stökl, "Schoolboy Ezekiel," 59-61.

88 Nevader, "On Reading Ezekiel," 100-101, 102 n. 10.

89 Even if Isa 47 was composed in Neo-Babylonian Judah, it would not affect the thesis presented here. I agree with Blenkinsopp, who argues that "The author would not have had to be a Babylonian resident to possess the knowledge about Babylonian religious practices evinced by these chapters. Judah and southern Babylonia were part of the same empire, and the biblical texts indicate frequent contact between them" (Isaiah 40-55, 103). Nissinen states the same for the Book of Ezekiel: the authors did not have to reside in Babylonia in the exilic period to have been familiar with Mesopotamian traditions. These traditions were known across the Near East, even in the Achaemenid and Hellenistic periods; Nissinen, “(How) Does the Book of Ezekiel," 96. 
attending the ceremony in person. It is questionable whether a first- or secondgeneration exile, notwithstanding his high level of literacy in Akkadian, which in itself is already debatable, would have had easy access to such a learned text as Maqlû, which does not seem to have circulated widely. My hesitation is further based on the scant evidence for the actual performance of the ceremony. The Maqlû ritual is mentioned in a letter written by an exorcist to the Neo-Assyrian king Esarhaddon in August 670 вСЕ,$^{90}$ which may underline the idea that the practical use of the Maqlû incantations and techniques was restricted to the upper social stratum. ${ }^{91}$ Apart from this letter, no archaeological evidence has been discovered in the sands of time that bears witness to the actual performance of Maqlu..$^{92}$

Although Deutero-Isaiah may not have had direct access to the actual Maqlû text or ceremony, he seems to have been aware of the main ideas reflected in them, either through common knowledge or by witnessing similar, yet simplified and popularized rites. This would explain why Deutero-Isaiah lacks the sophisticated knowledge of Maqlû and there is no one-to-one correspondence between the two sources, but rather a lexical and thematic overlap. Notwithstanding the vastly different genres of the two texts, ${ }^{93}$ his polemical stance towards Babylonian magical beliefs and practices may have also prevented him from adding further Maqlû related material. Nevertheless, Deutero-Isaiah conjures up an image of sorceress Babylon that mirrors the

9o $\quad A B L 5^{6}$ (= LAS 208); cf. Abusch, "Mesopotamian Anti-Witchcraft Literature," 259.

91 The average citizen may nevertheless have resorted to simplified and popularised anti-witchcraft rites. Further on the social setting of the Maqlû ceremony, see Abusch, "Demonic Image," 32, 53 n. 12; Farber, "Witchcraft, Magic, and Divination," 1903.

92 In 1974 Gasche excavated a small male clay figurine at Tell ed-Dēr (Sippar-Amnanum in the Old-Babylonian period). The figurine, dated to the seventeenth century ВСE, had been perforated; hence Gasche's suggestion that it may have been used in a magical ritual, thereby referring to Maqlû (see, for example, viII 39); Gasche, "Une figurine d'envoûtement paléobabylonienne"; cf. Schwemer, Abwehrzauber, 209-214. Schmandt-Besserat ("Human Clay Figurines") has discussed 49 Pre-Pottery Neolithic B and Yarmoukian anthropomorphic clay figurines excavated between 1982 until 1998 at 'Ain Ghazal, Jordan. Some of the figurines were pierced, showed traces of string, or were burned before the clay had even dried. Although these figurines are from a far-more-distant past than the Mesopotamian antiwitchcraft corpus, the author suggests that some of the rituals may have been similar.

93 I agree with Bowen, who observed the following, with regard to the different genres of Ezek 13 and Maqlû: "It should be taken into account that the primary differences between the oracle in Ezekiel and the Maqlû incantations are in genre and voice. It is the difference between an oracle and a prayer and the difference between an address by the deity and an address to the deity" ("Daughters of Your People," 421). Exactly the same can be said for Isa 47 and Maqlû. 


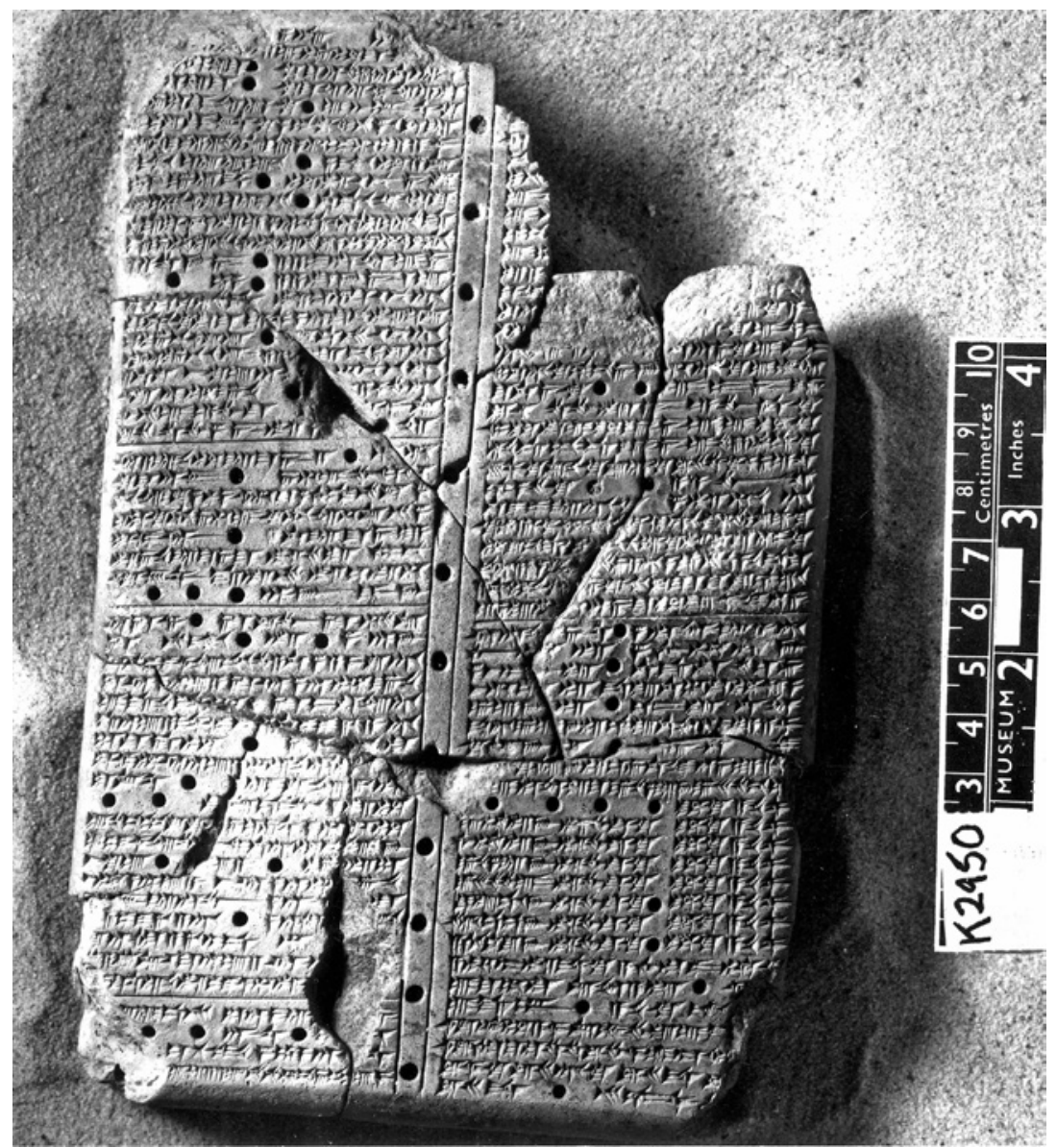

FIGURE 1 Nearly complete copy of Tablet VII of the Maqlû series from Ashurbanipal's library in Nineveh. Held in the British Museum, London (K 2950)

(C) THE TRUSTEES OF THE BRITISH MUSEUM. SHARED UNDER A CREATIVE COMMONS ATTRIBUTION-NONCOMMERCIAL-SHAREALIKE 4.0 INTERNATIONAL (CC BY-NC-SA 4.0) LICENCE

figure of the witch in Maqlü. Both enchantresses have too much in common to explain the similarities away as widespread literary tropes or stereotypes.

\section{Acknowledgment}

It is a great pleasure to thank Prof. Tzvi Abusch, Dr. Ann Jeffers, the anonymous reviewers, and the journal's editor, Prof. Annette Schellenberg, for reading this 
paper and kindly offering their expertise. I bear sole responsibility, however, for any errors that this paper may contain.

\section{Abbreviations}

ABL Harper, Robert F., and Leroy Waterman, Assyrian and Babylonian Letters Belonging to the Kouyunjik Collection of the British Museum. 14 vols. Chicago: University of Chicago Press, 1892-1914.

вDв Brown, Francis, Samuel R. Driver, and Charles A. Briggs. A Hebrew and English Lexicon of the Old Testament. Oxford: Clarendon Press, 1906.

BHS Biblia Hebraica Stuttgartensia. Edited by Karl Elliger and Willhelm Rudolph. Stuttgart: Deutsche Bibelgesellschaft, 1983.

CAD The Assyrian Dictionary of the Oriental Institute of the University of Chicago. Edited by Martha T. Roth et al. 21 vols. Chicago: Oriental Institute of the University of Chicago, 1956-2010.

DULAT del Olmo Lete, Gregorio, and Joaquín Sanmartín. A Dictionary of the Ugaritic Language in the Alphabetic Tradition. Translated and edited by Wilfred Watson. 2 vols. 3rd rev. ed. Leiden: Brill, 2015.

GKC Gesenius' Hebrew Grammar. Edited by Emil Kautzsch. Translated by Arthur E. Cowley. 2nd ed. Oxford: Clarendon Press, 1910.

HALOT Koehler, Ludwig, Walter Baumgartner, and Johann J. Stamm. The Hebrew and Aramaic Lexicon of the Old Testament. Translated and edited under the supervision of Mervyn E. J. Richardson. 5 vols. Leiden: Brill, 1994.

Joüon Joüon, Paul. A Grammar of Biblical Hebrew. Translated and revised by Takamitsu Muraoka. 2nd ed. Rome: Pontifical Biblical Institute, 2006.

LAS Parpola, Simo. Letters from Assyrian Scholars to the Kings Esarhaddon and Assurbanipal, Part I: Texts. AOAT 5/1. Neukirchen-Vluyn: Butzon \& Bercker, 1970.

\section{Bibliography}

Abusch, Tzvi. "Mesopotamian Anti-Witchcraft Literature: Texts and Studies; Part I:The Nature of Maqlu: Its Character, Divisions and Calendrical Setting." JNES 33 (1974): $251^{-262 .}$

Abusch, Tzvi. "An Early Form of the Witchcraft Ritual Maqlû and the Origin of a Babylonian Magical Ceremony." Pages 1-57 in Lingering over Words: Studies in Ancient Near Eastern Literature in Honor of William L. Moran. Edited by Tzvi Abusch, John Huehnergard, and Piotr Steinkeller. Hss 37. Atlanta: Scholars Press, 199 . 
Abusch, Tzvi. "Considerations When Killing a Witch: Developments in Exorcistic Attitudes to Witchcraft." Pages 65-78 in Mesopotamian Witchcraft: Toward a History and Understanding of Babylonian Witchcraft Beliefs and Literature. Edited by Tzvi Abusch. AMD 5. Leiden: Brill, 2002.

Abusch, Tzvi. "The Demonic Image of the Witch in Standard Babylonian Literature: The Reworking of Popular Conceptions by Learned Exorcists." Pages 3-25 in Mesopotamian Witchcraft: Toward a History and Understanding of Babylonian Witchcraft Beliefs and Literature. Edited by Tzvi Abusch. AMD 5. Leiden: Brill, 2002.

Abusch, Tzvi. "The Socio-Religious Framework of the Babylonian Witchcraft Ceremony Maqlû: Some Observations on the Introductory Section of the Text, Part I." Pages 1-34 in Riches Hidden in Secret Places: Ancient Near Eastern Studies in Memory of Thorkild Jacobsen. Edited by Tzvi Abusch. Winona Lake: Eisenbrauns, 2002.

Abusch, Tzvi. "Witchcraft Literature in Mesopotamia." Pages $373-385$ in The Babylonian World. Edited by Gwendolyn Leick. New York: Routledge, 2007.

Abusch, Tzvi. The Witchcraft Series Maqlû. WAW 37. Atlanta: SB L Press, 2015.

Abusch, Tzvi. The Magical Ceremony Maqlû: A Critical Edition. AMD 10. Leiden: Brill, 2016.

Abusch, Tzvi, and Daniel Schwemer. Corpus of Mesopotamian Anti-Witchcraft Rituals. 3 vols. AMD 8/1-3. Leiden: Brill, 2011-2020.

Baltzer, Klaus. Deutero-Isaiah: A Commentary. Hermeneia. Minneapolis: Fortress, 2001. Blau, Josua. "Hōb̄ərē Šāmājim (Jes xlvii 13) = Himmelsanbeter?” VT 7 (1957): 183-184.

Blenkinsopp, Joseph. Isaiah 40-55: A New Translation with Introduction and Commentary. AB19A. New York: Doubleday, 2002.

Bowen, Nancy R. “The Daughters of your People: Female Prophets in Ezekiel 13:17-23." JBL 118 (1999): 417-433.

Driver, Godfrey R. "Linguistic and Textual Problems." JTs 36 (1935): 396-406.

Duhm, Bernhard. Das Buch Jesaia. Göttingen: Vandenhoeck, 1902.

Evans, John F. "Death-dealing Witchcraft in the Bible? Notes on the Condemnation of the 'Daughters' in Ezekiel 13:17-23." TynBul 65 (2014): 57-84.

Farber, Walter. "Witchcraft, Magic, and Divination in Ancient Mesopotamia." Pages 1895-1909 in Civilizations of the Ancient Near East, Volume III. Edited by Jack M. Sasson. New York: Simon \& Schuster Macmillan, 1995.

Finkelstein, Jacob J. "Hebrew חבר and Semitic *hbr." JBL 75 (1956):328-331.

Fitzgerald, Aloysius. "The Mythological Background for the Presentation of Jerusalem as a Queen and False Worship as Adultery in the от." свQ 34 (1972): 403-416.

Fitzgerald, Aloysius. “втWLT and вт as Titles for Capital Cities." свQ 37 (1975): 167-183. Franke, Chris. "Reversals of Fortune in the Ancient Near East: A Study of the Babylonian Oracles in the Book of Isaiah." Pages 104-123 in New Visions of Isaiah. Edited by Roy F. Melugin and Marvin A. Sweeney. JSOTSup 214. Sheffield: Sheffield Academic Press, 1996. 
Freedman, David N. "Mistress Forever: A Note on Isaiah 47:7." Bib 51 (1970): 538.

Gasche, Hermann. "Une figurine d'envoûtement paléo-babylonienne." Pages 97-101 in Beiträge zur Altorientalischen Archäologie und Altertumskunde: Festschrift für Barthel Hrouda zum 65. Geburtstag. Edited by Peter Calmeyer et al. Harrassowitz: Wiesbaden, 1994.

Goldingay, John, and David Payne. Isaiah 40-55: A Critical and Exegetical Commentary. 2 vols. ICC. London: T\&T Clark, 2002-2007.

Hamori, Esther J. Women's Divination in Biblical Literature: Prophecy, Necromancy, and Other Arts of Knowledge. New Haven: Yale University Press, 2015.

Held, Moshe. "Studies in Biblical Lexicography in the Light of Akkadian." ErIs 16 (1982): 76-85. (Hebrew)

Hermann, Johannes. Ezechiel übersetzt und erklärt. Leipzig: A. Deichert, 1924.

Jeffers, Ann. Magic and Divination in Ancient Palestine and Syria. Studies in the History and Culture of the Ancient Near East 8. Leiden: Brill, 1996.

Jeffers, Ann. "Wicked Witches of the West: Construction of Space and Gender in Jezreel." Pages 76-91 in Constructions of Space IV: Further Developments in Examining Social Space in Ancient Israel. Edited by Mark George. London: T\&T Clark, 2013.

Kabamba Kiboko, Jeanne. Divining the Woman of Endor: African Culture, Postcolonial Hermeneutics, and the Politics of Biblical Translation. Lвнотs 644. London: T\&T Clark, 2017.

Korpel, Marjo. "Avian Spirits in Ugarit and in Ezekiel 13." Pages 99-113 in Ugarit, Religion and Culture: Proceedings of the International Colloquium on Ugarit, Religion and Culture, Edinburgh, July 1994. Edited by Nick Wyatt et al. Münster: Ugarit-Verlag, 1996.

Levine, Baruch A. In the Presence of the Lord: A Study of Cult and Some Cultic Terms in Ancient Israel. Leiden: Brill, 1974.

Luukko, Mikko. Grammatical Variation in Neo-Assyrian. SAAS 16. Helsinki: The NeoAssyrian Text Corpus Project, 2004.

Mankowski, Paul V. Akkadian Loanwords in Biblical Hebrew. Hss 47. Winona Lake: Eisenbrauns, 2000.

Morgenstern, Julian. "The Message of Deutero-Isaiah in its Sequential Unfolding." HUCA 29 (1958): 1-67; 30 (1959): 1-102.

Nevader, Madhavi. “On Reading Ezekiel by the Rivers of Babylon.” wo 45 (2015): 99-110.

Nissinen, Martti. “(How) Does the Book of Ezekiel Reveal Its Babylonian Background?” WO 45 (2015): 85-98.

Reiner, Erica. Astral Magic in Babylonia. Philadelphia: American Philosophical Society, 1995 .

Rendtorff, Rolf. "The Book of Isaiah-A Complex Unity: Synchronic and Diachronic Reading." Pages 32-49 in New Visions of Isaiah. Edited by Roy F. Melugin and Marvin A. Sweeney. JSOTSup 214. Sheffield: Sheffield Academic Press, 1996. 


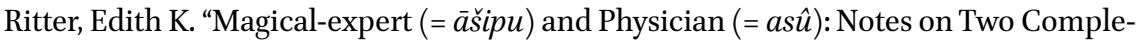
mentary Professions in Babylonian Medicine.” Pages 299-321 in Studies in Honor of Benno Landsberger on His Seventy-fifth Birthday, April 21, 1963. Edited by Hans G. Güterbock and Thorkild Jacobsen. AS 16. Chicago: University of Chicago Press, 1965. Rollin, Sue. "Women and Witchcraft in Ancient Assyria (c. 9oo-6oо BC)." Pages 34-46 in Images of Women in Antiquity. Edited by Averil Cameron and Amélie Kuhrt. 2nd ed. London: Routledge, 1993.

Schmandt-Besserat, Denise. "The Human Clay Figurines and Ancient Near Eastern Magic." Pages 113-167 in Symbols at 'Ain Ghazal. Edited by Denise Schmandt-Besserat. Berlin: Ex Oriente, 2013.

Schrader, Eberhard. Die Keilinschriften und Das Alte Testament. Edited by Heinrich Zimmern and Hugo Winckler. 3rd ed. Berlin: von Reuther \& Reichard, 1903.

Schwemer, Daniel. Abwehrzauber und Behexung: Studien zum Schadenzauberglauben im alten Mesopotamien; Unter Benutzung von Tzvi Abuschs Kritischem Katalog und Sammlungen im Rahmen des Kooperationsprojektes Corpus of Mesopotamian Anti-Witchcraft Rituals. Wiesbaden: Harrassowitz Verlag, 2007.

Schwemer, Daniel. "Evil Witches, Apotropaic Plants and the New Moon: Two AntiWitchcraft Incantations from Babylon (BM 35672 and BM 36584)." wo 41 (2011): 177-187.

Schwemer, Daniel. "Mesopotamia." Pages 36-64 in Guide to the Study of Ancient Magic. Edited by David Frankfurter. RGRW 189. Leiden: Brill, 2019.

Scurlock, JoAnn. "Physician, Exorcist, Conjurer, Magician: A Tale of Two Healing Professionals." Pages 69-79 in Mesopotamian Magic: Textual Historical, and Interpretative Perspectives. Edited by Tzvi Abusch and Karel van der Toorn. AMD 1. Groningen: Styx, 1999.

Sefati, Yitzhak, and Jacob Klein. "The Role of Women in Mesopotamian Witchcraft." Pages 569-587 in Sex and Gender in the Ancient Near East: Proceedings of the 47th Rencontre Assyriologique Internationale, Helsinki, July 2-6, 2001. Vol. 2. Edited by Simo Parpola and Robert Whiting. Helsinki: The Neo-Assyrian Text Corpus Project, 2002.

Silverman, Jason M. Persian Royal-Judaean Elite Engagements in the Early Teispid and Achaemenid Empire: The King's Acolytes. Lнвотs 69о. London: T\&T Clark, 2019.

Smith, Mark S. "The Magic of Kothar, the Ugaritic Craftsman God, in KTU 1.6 VI 49-50." $R B$ 91 (1984): 377-380.

Sommer, Benjamin D. "Allusions and Illusions: The Unity of the Book of Isaiah in Light of Deutero-Isaiah's Use of Prophetic Tradition." Pages 156-186 in New Visions of Isaiah. Edited by Roy F. Melugin and Marvin A. Sweeney. JSOTSup 214. Sheffield: Sheffield Academic Press, 1996.

Stökl, Jonathan. "Schoolboy Ezekiel: Remarks on the Transmission of Learning." wo 45 (2015): 50-61. 
Stratton, Kimberly B., and Dayna S. Kalleres, eds. Daughters of Hecate: Women and Magic in the Ancient World. New York: Oxford University Press, 2014.

Thomsen, Marie-Louise. "Witchcraft and Magic in Ancient Mesopotamia." Pages 1-95 in Witchcraft and Magic in Europe. Vol. 1: Biblical and Pagan Societies. Edited by Bengt Ankarloo and Stuart Clark. London: Athlone Press, 2001.

Ullendorff, Edward. "Ugaritic Marginalia II." Jss 7 (1962): 339-351.

Van Buylaere, Greta. "The Decline of Female Professionals - and the Rise of the Witch-in the Second and Early First Millennium всE." Magic, Ritual, and Witchcraft 14 (2019): 37-61.

Vanderhooft, David S. The Neo-Babylonian Empire and Babylon in the Latter Prophets. HSM 59. Atlanta: Scholars Press, 1999.

Vanderhooft, David S. "Ezekiel in and on Babylon." Pages 99-119 in Bible et ProcheOrient: Mélanges André Lemaire III. Edited by Josette Elayi and Jean-Marie Durand. Transeu 46. Paris: Gabalda, 2014.

Winitzer, Abraham. "Assyriology and Jewish Studies in Tel Aviv: Ezekiel Among the Babylonian Literati." Pages 163-216 in Encounters by the Rivers of Babylon: Scholarly Conversations between Jews, Iranians, and Babylonians in Antiquity. Edited by Uri Gabbay and Shai Secunda. TSAJ 16o. Tübingen: Mohr Siebeck, 2014.

Zimmern, Heinrich. Akkadische Fremdwörter als Beweis für babylonischen Kultureinfluss. Leipzig: Hinrichs, 1915. 